\title{
National Value Education According to Ki Hajar Dewantara in the Axiological Perspective and Its Relevance with the Education of the Young Generation
}

\author{
Suprayogi ${ }^{1}$, Giri Harto Wiratomo ${ }^{2}$ \\ \{suprayogi@gmail.com ${ }^{1}$, girihartowiratomo@mail.unnes.ac.id ${ }^{2}$ \} \\ Universitas Negeri Semarang, Indonesia ${ }^{1,2}$
}

\begin{abstract}
Understanding the national values of the younger generation has decreased. Even though the national values that are owned and lived well are believed to be the binder of national life which has a very significant contribution to the existence of the life of a nation and country. Owned, lived and maintained the national values of a nation are closely related to the quality of the implementation of the national education system. This article will examine the education of national values according to Ki Hajar Dewantara in axiological perspective and its relevance to the education of the younger generation. This research is in this field of philosophy, with formal axiological objects and educational material objects of national values according to Ki Hajar Dewantara. The research aims to find the education of national values according to Ki Hajar Dewantara and analyze the value of nationality according to Ki Hajar Dewantara in the value hierarchy. The technique of collecting data is by reading symbolic levels, taking notes, and capturing the essence of education of national values according to Ki Hajar Dewantara. Analysis of value hierarchy using the theory of Max Scheler. The results of this study are the education of national values according to Ki Hajar Dewantara is the guidance of life and the growth of children in sowing and raising feelings, understanding, enthusiasm, and national insight, high, deep, and limited by human and national cultural conditions to guide natural forces children become citizens of the nation, thus achieving safety and happiness. The national values according to Ki Hajar Dewantara materially in the value hierarchy according to Max Scheler are spiritual/psychological values. The function of the national values according to Ki Hajar Dewantara in the Max Scheler value hierarchy is the vital value of national life. The education of national values according to Ki Hajar Dewantara has very high relevance to the education of the younger generation, namely as a character builder to ensure the continuity of the life of the Indonesian nation and state.
\end{abstract}

Keywords: National Values, Axiological, Value Hierarchy, Young Generation.

\section{Introduction}

Every nation wants its national or national life to exist. The national values that are owned, lived and preserved as a binder of national life contribute significantly to the existence of a nation's life. Owned, internalized and maintained national values are closely related to the quality of the implementation of the national education system, so that the existence of a nation's life is determined by how the nation views and manages its national education. Plato 
stated: Ideally in a country education gets the most important place and gets the most special attention [1].

Globalization contributes to the decline in national values in Indonesia. Globalization is a necessity and is often seen as an open wide opportunity, actually stretching challenges, even appearing as a problem [2]. Globalization as an opportunity and challenge must be addressed wisely, so that it does not have a negative impact. A nation that is unable to face globalization will be swept away and destroyed its personality. A nation that is left behind will fall prey to a developed nation. So what is faced is the problem of maintaining the survival of the nation [3]. Globalization makes life change fast, a culture that was first not really interpreted, but has been replaced by another and foreign cultures. Such a situation implies that there is no reference for the younger generation in shaping their personalities and identities, so nationalism based on national values must be refreshed and continued to grow from generation to generation [4]. The important role of education in national life is not new, all nations look at their education when facing problems [5].

The answer to the problem is how education is seen, managed, implemented, contains what, and how, is related to the foundation of the philosophy of education. The philosophy of education is essentially the application of philosophical analysis to the field of education. Philosophy is a general theory of education, the foundation of all thinking about education [6]. The problems of education that must be answered include the problem of education that does not Indonesia, overemphasizes the cultivation of the brain, and the Indonesian identity crisis which destroys the sense of belonging to one's own culture [6].

The orientation of national education emphasizes cognitive, parsialistic, and tends to give less attention to the development of attitude aspects, so that the younger generation lacks a system of values and attitudes, including national values [7]. The concept of existing education does not have a strong footing, and its meaning has been reduced only to prepare students to get jobs in the industry [8]. Education of national values for the Indonesian people is a necessity. Diversity if it is not based on a strong nationalistic spirit and a solid foundation of the nation's view of life, the national ties can be slackened, even completely off [9]. The sense of nationality does not grow by itself, but must be instilled through education [10].

Ki Hadjar Dewantara gave an answer to the question "What education is most suitable for Indonesian children?" The most appropriate answer to the problem is: National Education [11]. National teaching that is in harmony with the livelihood of the nation (maatschappelijk) and the life of the nation (cultutureel) as intended is nothing but nationality education or nationalism-oriented education. This research is a literature research in philosophy. Formal objects involve the point of view, while material objects are objects which are the focus of studies of a particular science [12]. Material objects are the education of national values according to Ki Hajar Dewantara, while the formal object is axiology, especially the value hierarchy.

\section{Result and Discussion}

National Value Education according to Ki Hajar Dewantara. Ki Hajar Dewantara believes that education for the nation's children has very deep meaning and meaning as the nurturer and developer of the seeds of national unity [11]. Education is the preserver and developer of national seeds, aimed at instilling the value of togetherness as a nation, regardless of social class, race, ethnicity, religion, customs, and so forth. Education is an instrument that has the power to be able to unite all components of the nation in a single state. 
The concept of education of the Dutch colonial government only emphasizes reason alone by ignoring reason to sharpen the social sensitivity of a nation must be abandoned, because the concept of education thus destroys the life of the Indonesian nation according to its cultural nature. Ki Hajar Dewantara [13] firmly stated: Colonial education was not based on needs as a nation, because it was present for the benefit of the colonial government. The contents are not in accordance with the circumstances and demands for the advancement of the Indonesian soul. Colonial education made the Indonesian people dependent on other nations. Ki Hajar Dewantara [13]considers: Colonial education is not able to present the fairy of life together, so it depends on the invaders.

Such conditions will not disappear if only opposed by politics, it must be prioritized to spread the seeds of free life among the Indonesian people with teaching accompanied by the spirit of nationalism. Ki Hajar Dewantara believes that education as a guideline must contain the education of national values that sow and fuel Indonesian nationalism [28]. Education as a guide that sows and inflames national values clearly and firmly stated by Ki Hajar Dewantara [14], Base all efforts of education and teaching on the basis of Indonesian nationality in a broad, high and deep sense, and are only limited by humanitarian standards such as meant by all religious teachings. Respect all the strong, healthy customs, which are found in the regions and which do not interfere or hinder the unity of the state and nation of Indonesia.

Ki Hajar Dewantara [14] suggested the basis of national education, namely: First; Maintain and strengthen the love of nusa and the nation in the hearts of students by incorporating the spirit of nationalism in all lessons, and negating the content of teaching which weakens the spirit of nationalism. Second; Hold ceremonies and regulations, as well as special training and teaching that thickens the awareness and love of the nation, especially those who affirm love, pride, and loyalty to the country of Indonesia. Instead eliminate all ceremonies and regulations that are not in accordance with the spirit of nationalism. Raise the Red and White and sing Indonesia Raya as the guardian of Indonesia's patriot spirit. Third; Use all the strength and strength of bodies such as Gakukotai, Seinendan, Keibodan, and others to strengthen the national movement, after the body is adapted to an atmosphere of nationality and does not interfere with teaching interests.

\subsection{The national concept of Ki Hajar Dewantara}

The national concept of Ki Hajar Dewantara can be understood by analyzing his writing in Pusara Magazine which was published in May 1932 Dj. II No. 5 and 6 [15] namely: First; The sense of nationality is a part of the mysticism that lives in the soul and grows by itself. Beginning arises from a sense of self that is carried away from the state of life, then a sense of family emerges. Family sense continues to be a sense of living together (social sense). The form of nationalism generally unites the interests of the nation with the person, the destiny of the nation as its own destiny, the honor of the nation is self-respect. Second; A sense of self flows into a sense of family, and a sense of nationality grows along with the growth of equality of interests and circumstances, both physically and mentally. Furthermore, there was an equality of customs which gave rise to the rules of order and peace in the common life. Third; The occurrence of national unity of the people is not sudden, but has a background of unifying historical equality, especially the unification of mystical values through tambo (history), language, art, religion, and knowledge. Fourth; The sense of nationality in Indonesia is synonymous with nationalism. Fifth; The sense of nationality will grow by itself and it is not realized to unite the sense of the same boat, countryman, language, and setambo. 
Sixth; In time, the sense of nationality grew as ideals that were felt as the interests of the nation which was pushed by the interests of other nations. The emergence of a sense of nationality often beat other flavors. Seventh; A sense of nationality with full awareness raises the desire, willingness, and energy that aims at the glory of the nation with various unified and united efforts, namely, to encourage self-care or encourage the nation's independence movement. Eighth; The strength of the nation's independence movement is closely related to the character of the people of the nation. Nine; The strength of the nation's independence movement is very dependent on the degree of urgency of the nation's interests. As long as a nation feels deprived of its rights, then the movement will continue. Ten; The national movement defeats self-interest and is idealistic, including the field of education which inspires people's enthusiasm to be aware of their nationality. Eleven; Various national differences that exist, bring consequences to the emergence of different nations, in harmony with nature and human iradat, to discipline and advance their lives. Twelve; The growing national movement will continue, because it is driven by economic conditions. The Indonesian nation will uphold its humanitarian civilization, if the goal has been achieved, namely as a nation can live a normal life not colonized by other nations.

Ki Hajar Dewantara explained the concept of nationality [16] as: A love for a nation that became the soul of a national life belief. The love of a high nation requires the ability to defend and give up oneself, each in its place, not for one's own benefit, nor from the point of view of the interests of the nation, but from the point of its kindness which is the peak of humanity's progress. A healthy national life belief is an embodiment of humanitarianism. The movement of the national belief struggle must first be aimed at forming a society that can ensure the nation's progress as widely as possible.

\subsection{Value Hierarchy According to Max Scheler}

Humans in their lives cannot be separated from value problems. Humans are aware of or do not make judgments in their relationships between humans and their environment [17]. Kattsoff [18] quotes Ralph Barton Perry in his article General Theory of Value that: Every object that exists in reality or in the mind can obtain value. The important thing about value theory is about the basis of values and the location of values in the universe. The concept of value is a complement and also the opposite of the concept of fact. Humans only know the facts, but must look for values [19].

Values are always in a hierarchical arrangement (level), which is in relation to each other as higher or lower. Feelings of value have their basis in preference actions. Value hierarchy according to Max Scheler [3] there are four levels, namely: First: Value of pleasure. The value of pleasure, the value of distress, or the value of pleasure and pain is at the lowest level. The level of pleasure value is related to the function of sensory feeling, namely pleasure or pain or pain. Precociously everyone will choose the fun rather than the unpleasant. Second: Value of vitality or life. The value of vitality or life consists of the sense of life, which includes the sublime, subtle or gentle, to the crude or ordinary, and also includes the good (in a special sense) that is the opposite of the bad. Related conditions are health, vitality, disease, aging, weakness, and a sense of being near death. The value of vitality presents a feeling that is totally independent and cannot be reduced or returned either at a higher level of value (spiritual value) or at a lower level of value (usability or pleasure). Third: Spiritual values. Spiritual values have properties that do not depend on all the physical environment and the surrounding natural environment. This value is higher than the value of vitality, because to 
realize the spiritual value one must sacrifice the value of vitality. Spiritual values can be captured with a spiritual sense and in the act of spiritual preference, namely, to love and hate.

The basic types of spiritual value are a) aesthetic values; b) the value of right and wrong or fair and unfair as the basis of an objective legal order; and c) the value of pure knowledge for his own sake. Fourth: Value of sanctity or profession. This value can be captured by humans in the intended object as an absolute object. The level of the value of chastity does not depend on the difference in time and differences in the people who carry it. The feeling associated with this value is a feeling of blessing and a sense of hopelessness as its closeness to the sacred, which must be distinguished from just feeling happy and difficult. The catch of spiritual values is related to feeling of faith and not believing, admiring, praising, and worshiping in achieving holiness which is personally directed towards the person.

\subsection{Critical Analysis of National Value according to Ki Hajar Dewantara in the Value Hierarchy}

Values and humans are two things that influence each other influence, humans need and determine values, on the contrary there is value and is needed by humans. The Indonesian people in their lives need values to live the life they aspire to. The national values according to Ki Hajar Dewantara are one of them, a very necessary value in the life of the Indonesian nation to live and achieve the life they aspire to. The hierarchy of values is an arrangement of higher levels decreasing to a lower level which is a priori [3]. All values are basically in a hierarchical arrangement. The hierarchical arrangement can never be deduced or translated logically. Which values are higher than others can only be known through preference actions. The hierarchy of values is stated by Max Scheler, Notonagoro, and Driyarkara.

The study of national values according to Ki Hajar Dewantara in the value hierarchy will be meaningful and useful for understanding, accepting, and ultimately the beliefs and appreciation of the national values of the Indonesian people in the life of the community, nation and state. A philosophical study means proof that reinforces the understanding, acceptance, belief and appreciation of the national values of the Indonesian people. Understanding, acceptance, belief, and appreciation of the values of a solid nationality will provide added value, clarity, and firmness to improve the quality of life of the nation.

LAN RI [20] emphasizes: Understanding and accepting good and solid national values supports the formation of whole Indonesian people as objects and subjects of national development towards a just and prosperous society based on Pancasila. Subagyo [26] stated the importance of the process of awareness of national values to the younger generation: The young generation of nationalities must reflect awareness of national values in order to grow and develop again, given the depletion of nationalism, the need to take oaths of youth again or be sworn.

The analysis of the national values according to Ki Hajar Dewantara in the value hierarchy implies analyzing the position of national values according to Ki Hajar Dewantara in the value hierarchy according to Max Scheler, Notonagoro, and Driyarkara, so that they are known and understood at which level or where. Analysis of the national values according to Ki Hajar Dewantara to know and understand the exact position in the value hierarchy was taken through two ways or ways. First, the value of nationalism according to Ki Hajar Dewantara is seen as material or goods. This method of analysis is included in the class of values, whether the level of nationality according to Ki Hajar Dewantara is substantially material or the items in the hierarchy of values according to Max Scheler, Notonagoro, and Driyarkara. Second, the value of nationalism according to Ki Hajar Dewantara is seen in its function or usefulness. 
This method of analysis is included in the class of values, and which level of value of nationality according to Ki Hajar Dewantara is substantially function or useful in the value hierarchy according to Max Scheler.

\subsection{Discussion}

Ki Hajar Dewantara related to the relevance of education for national values for the younger generation with the view:

a. National education must be teaching that is in harmony with the nation's livelihood (maatschappelijk) and national life (cultureel), so that it contains the value of education that is able to foster the spirit of loving the nation and country [14]

b. The era of openness requires the Indonesian people to prepare the young generation with a rooted personality above their culture to become a necessity [14]

c. Ethical education must be carried out based on the appropriate and useful national values with the demands of the times [14]

d. Education in the future must be able to grow and mature the national awareness of the younger generation [14]

e. National education must encompass the three centers of education, and the education of the young generation who develop national values must receive special attention from the government [14]

f. Education has the main task of inculcating the values of life and national life (nationaal), natural nature (natuurlijk) or humanitarian ways (menschelijk) [14]

g. The subject matter must contain knowledge and general intelligence and character education, especially education in the spirit of work, family, worship, love for the country, and defending the country [14]

\section{Conclusion}

The education of national values according to Ki Hajar Dewantara is guidance in the life and growth of children who always sow and inflame their sense, understanding, enthusiasm, and insight into the nationality of Indonesia, high and deep, and limited by the human and cultural conditions of the nation, with the aim of guiding the natural strength of children to become citizens of the nation who can achieve the highest safety and happiness. The national values according to Ki Hajar Dewantara in the value hierarchy according to Max Scheler in material terms are spiritual or psychological values, namely values that have properties not dependent on the entire physical environment and the natural environment. Functionality or usefulness of national values according to Ki Hajar Dewantara is the vitality of life (rightwrong). Relevance of Education the value of nationalism according to Ki Hajar Dewantara with the education of the young generation is very high. The young generation is human resources, national assets, heirs, pioneers, agents of change, and fillers and determinants of the future of the life of the nation and state of Indonesia. National values must be developed through education as a builder of the character of the young generation.

\section{References}


[2] K. Sutikno, Ketamansiswaan I, Universitas Sarjanawiyata Tamansiswa. Yogyakarta, 2003.

[3] P. Wahana and M. Hum, Pustaka Filsafat Nilai Etika Aksiologis Max Scheler. Kanisius, 2004.

[4] S. Yudohusodo and I. Y. P. B. (Jakarta, Semangat baru nasionalisme Indonesia. Yayasan Pembangunan Bangsa, 1996.

[5] Zamroni, Pendidikan dan Demokrasi dalam Transisi PSAP Muhamadiyah. Jakarta, 2007.

[6] I. Barnadib, "Filsafat Pendidikan: Sistem dan Metode," Yogyakarta, Andi Ofset, 1994.

[7] D. Soeratman, Ki Hajar Dewantara,. Jakarta: Departemen Pendidikan dan Kebudayaan, 1985.

[8] Gunawan, Menuju Jati Diri Pendidikan Yang Mengindonesia. Yogyakarta: Gadjah Mada University Press, 2009.

[9] Hernowo, Implementasi Pancasila Menjamin Integrasi Nasional Berwawasan Kesatuan dan Persatuan Bangsa,. Jakarta: LPPPKB, 2006.

[10] J. Siswanto, "Metafisika sistematik," Taman Pustaka Kristen, 2004.

[11] M. Yamin, Menggugat Pendidikan Indonesia: Belajar dari Paulo Freire dan Ki Hajar Dewantara. Ar-Ruzz Media, 2009.

[12] M. S. Kaelan, "Metode Penelitian Kualitatif Bidang Filsafat," Paradig. Yogyakarta, 2005.

[13] K. H. Dewantara, "Menuju Manusia Merdeka Ki Hadjar Dewantara," Yogyakarta: Leutika, 2009 .

[14] K. H. Dewantara, "Karya Ki Hadjar Dewantara," Bagian pertama Pendidikan. Yogyakarta Majelis Luhur Persat. Taman Siswa, 1977.

[15] K. H. Dewantara, Kebudajaan. Madjelis-Luhur Persatuan Taman-Siswa, 1967.

[16] T. T. Sumitro, Siswono, Wiryono, Pramudyakara, Kaum Muda dan Kebangsaan (Bunga Rampai Seminar), . Jakarta: Yayasan Pembangunan Bangsa, 1996.

[17] B. Daroeso, Dasar dan konsep pendidikan moral Pancasila. Aneka ilmu, 1986.

[18] L. O. Kattsoff, "Pengantar Filsafat, alih bahasa Soejono Soemargono," Yogyakarta: Tiara Wacana Yogya, 1996.

[19] L. Bagus, Kamus Filsafat. Jakarta: PT Gramedia Pustaka Utama, 2005.

[20] L. A. Negara, "Wawasan Kebangsaan Dalam Kerangka Negara Kesatuan Republik Indonesia," Jakarta, LAN, 2014 